\title{
ASPECTOS GEOAMBIENTAIS NO PARQUE ESTADUAL DA SERRA DOS MONTES ALTOS-BA
}

\author{
Claudineia Alves Teixeira \\ Pós-Graduanda em Docência do Ensino Superior - UNOPAR \\ Professora da Secretaria de Educação do Estado da Bahia - SEEBA, Caetité, BA, Brasil \\ claudineiaalves.t@gmail.com
}

Junívio da Silva Pimentel

Mestre em Ciências Geodésicas e Tecnologias da Geoinformação - UFPE Professor Assistente na Universidade do Estado da Bahia - UNEB, Campus VI, Caetité, BA, Brasil juniviopimentel@yahoo.com.br

\begin{abstract}
RESUMO
A Serra de Monte Alto, localizada no Território de Identidade Sertão Produtivo, compreende partes de seis municípios da Bahia. Essa unidade de paisagem é composta por múltiplas riquezas, expressas em condicionantes naturais, e em largo patrimônio histórico relativo à presença de vida humana pretérita na região. Por conta disso, se criou o Parque Estadual da Serra dos Montes Altos e o Refúgio de Vida Silvestre da Serra dos Montes Altos, duas Unidades de Conservação com vistas à proteção e a conservação de sua biodiversidade. Este artigo objetiva realizar caracterização geoambiental do Parque, a fim de identificar efeitos obtidos com seu funcionamento, focando-se em aspectos vinculados a questões ambientais. O estudo foi balizado por contribuições teórico metodológicas de autores como Ab'Sáber (2003); MME (1982); Tasso (2012). Trata-se de pesquisa exploratória de caráter qualitativo e quantitativo, que se fundamenta no método Geossistêmico. Em termos procedimentais realizou-se buscas em referenciais bibliográficos e documentais, levantamentos cartográficos e produção de mapas e ilustrações. Desse modo, estabeleceuse a análise integrada da paisagem, chegando a resultados que permitiram concluir que a criação das Unidades de Conservação foi oportuna, já que tem contribuído significativamente para conservação e preservação do patrimônio ambiental e histórico.
\end{abstract}

Palavras-chave: Cartografia Ambiental. Parque. Serra de Monte Alto.

\section{GEOENVIRONMENTAL ASPECTS IN THE SERRA DOS MONTES ALTOS STATE PARK-BA}

\begin{abstract}
The Serra de Monte Alto, located in the Territory of Identity Productive Sertão, comprises parts of the territory of six municipalities of Bahia. This landscape unit is composed of multiple riches expressed in natural constraints and in large historical heritage related to the presence of past human life in the region. Because of this, the Serra dos Montes Altos State Park and the Serra dos Montes Altos Wildlife Refuge were created, two Conservation Units with a view to the protection and the conservation of its biodiversity. This article aims to perform geoenvironmental characterization of the Park, in order to identify effects obtained with its operation, focusing on aspects related to environmental issues. The study was marked by theoretical methodological contributions of authors withthe Ab'Sáber (2003); MME (1982); Tasso (2012). This is an exploratory research of qualitative and quantitative character, which is based on the Method Geossistemmic. In terms of procedimentais, searches were carried out in bibliographic and documentary references, cartographic surveys and production of maps and illustrations. Thus, an integrated analysis of the landscape was established, and I have achieved results that allowed us to conclude that the creation of conservation units was timely, since it has contributed significantly to conservation and preservation of environmental and historical heritage.
\end{abstract}

Keywords: Park. High Mountain Range. Environmental Cartography.

\section{INTRODUÇÃO}

A Serra de Monte Alto (SMA), localizada no Território de Identidade Sertão Produtivo, abrange os municípios de Candiba, Guanambi, Palmas de Monte Alto, Pindaí, Sebastião Laranjeiras e Urandi, no Estado da Bahia. Trata-se de uma área geologicamente sedimentar, que geomorfologicamente 
apresenta partes aplainadas e elevadas no seu modelado de relevo. Possui características climáticas do tipo semiárido e semiúmido, classes de solos com características físico químicas diferentes, variando entre tipologias mais profundas e outras ainda em processo de desenvolvimento (BAHIA, 2018).

A Serra apresenta vegetação característica dos biomas da Caatinga e do Cerrado e, área de transição, o que lhe confere alto grau de diversidade, sendo constatada a presença de espécimes rasteiras e de médio porte como florestas deciduais e matas de galeria (RODRIGUES, 2012). Sua fauna possui igual potencial de diversidade, apesar de limitadas informações disponíveis a respeito (SOARES FILHO, HARLEY e SOUZA, 2012). É uma região rica em recursos hídricos, abrigando importante rede de drenagem superficial e subterrânea, que abarca cursos d'água de relevância local e regional (RODRIGUES, 2012).

$\mathrm{Na}$ área, que é destaque na paisagem regional, já foram realizadas práticas econômicas que provocaram alterações no ecossistema local (RODRIGUES, 2012). Diante dessa e demais circunstâncias, criou-se duas Unidades de Conservação (UCs) para auxiliar na conservação da biodiversidade e corpos hídricos, além de favorecer o desenvolvimento de atividades socioambientais na área. A partir dos Decretos Estaduais o 12.486 e no 12.487 de 29 de novembro de 2010 criou-se o Parque Estadual da Serra dos Montes Altos (PESMA), com área estimada 18.491 ha, e o Refúgio de Vida Silvestre da Serra dos Montes Altos (RVSSMA), englobando aproximadamente uma área de 27.499 ha (BAHIA, 2010a, 2010b).

O Parque conta com cerca de 150 nascentes em sua região e entornos, abriga espécies raras e endêmicas eminentes de seu ecossistema de transição Caatinga-Cerrado na fauna e flora (SANCHES e BERNARDES, 2012). Possui patrimônio arqueológico que compreende a "Casa de Pedra", alinhamento de Menires e diversos painéis com inscrições rupestres e Toca dos Tapuios (INEMA, 2019).

Para conservar e preservar os ambientes terrestres deve-se obter conhecimentos sobre eles, identificar os elementos que os compõem para o planejamento de ações de manejo com vistas à proteção ambiental. É crucial entender sua importância para a manutenção da vida, sendo imperativo envolver diversos setores da sociedade, com participação/interação da população para que as UCs cumpram seu papel. A partir dessa perspectiva, o presente artigo objetiva realizar a caracterização geoambiental do Parque, a fim de identificar os efeitos obtidos com seu funcionamento, focando-se em aspectos vinculados às questões ambientais.

Assim, por meio de pesquisa exploratória, bibliográfica, documental, levantamento cartográfico e produção de mapas, coleta e análise de imagens orbitais, uso do método geossistêmico que engloba os aspectos presentes de maneira integrada e, optando pela categoria geográfica paisagem este artigo busca trazer para as discussões as problemáticas existentes na área, visando atender a carência de estudos relacionados à temática, e quiçá venha a preencher algumas lacunas com informações relevantes.

Com os resultados obtidos compreende-se que a área apresenta dinâmica ambiental diferenciada e sensível às alterações. Com efeito, a criação das UCs teve repercussão positiva para a conservação/proteção de seu patrimônio ambiental e histórico. Todavia, é imperativo criar e adotar gestão eficiente do Plano de Manejo (PA), bem como conscientizar a população na busca pelo desenvolvimento socioeconômico sustentável para garantir às gerações futuras acesso às suas paisagens e usufruto de seus recursos naturais.

\section{METODOLOGIA}

\section{Diretrizes norteadoras da investigação}

A área pesquisada (Figura 1) localiza-se no Território de Identidade Sertão Produtivo, abrangendo os municípios de Candiba, Guanambi, Palmas de Monte Alto, Pindaí, Sebastião Laranjeiras e Urandi, no Estado da Bahia (BAHIA, 2018). 
Figura 1 - Localização da área pesquisada.

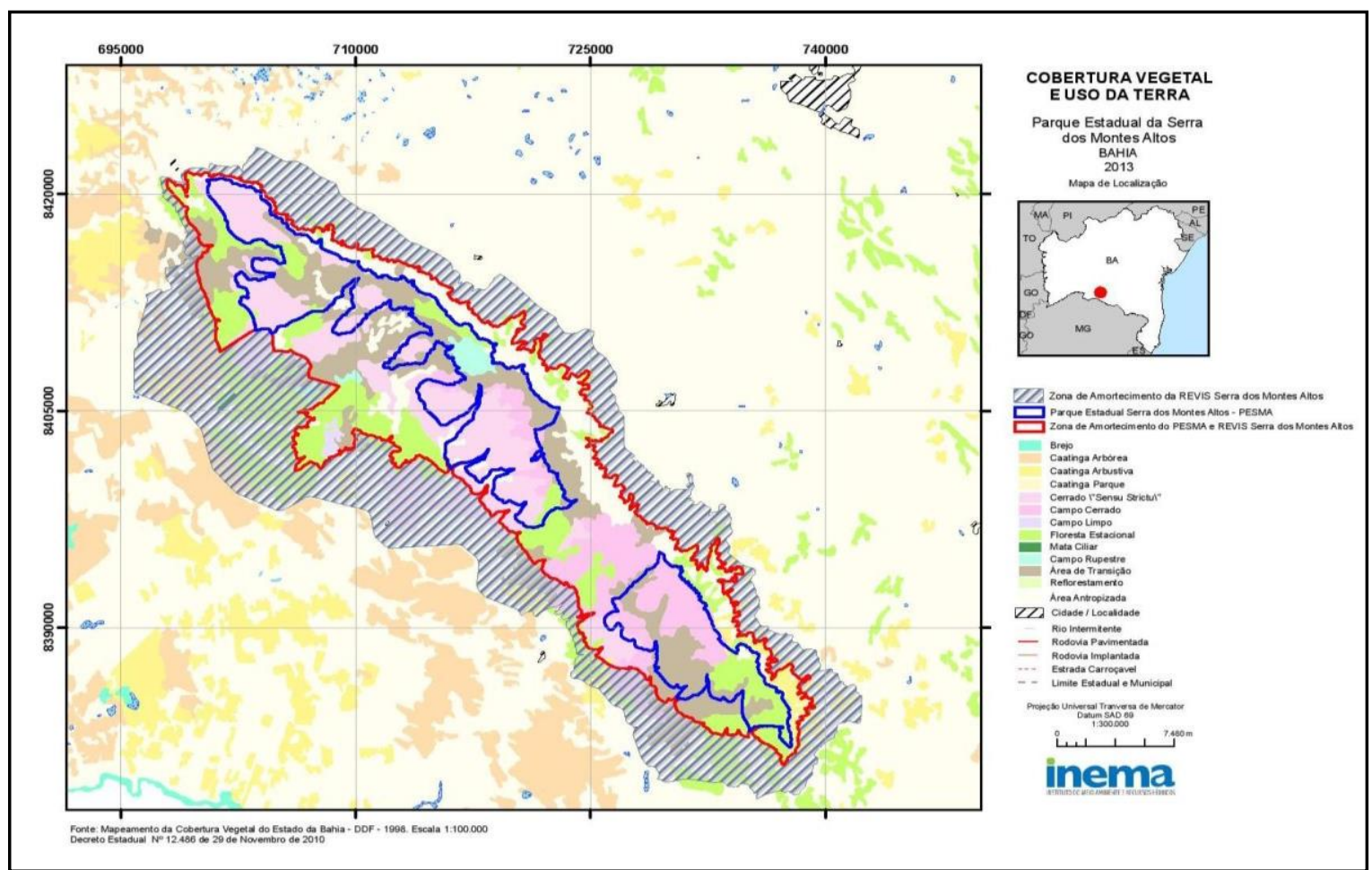

Fonte - INEMA (2013).

A fim de alcançar os objetivos propostos, esta pesquisa tem caráter exploratório e qualitativo, na qual se fez uso do método geossistêmico. Bertrand (1972) estabelece releituras de pressupostos de Sotchava (1963) ${ }^{1}$, percebendo o geossistema como uma combinação entre o potencial ecológico, a exploração biológica e a ação antrópica, os quais formam um sistema complexo em que cada peça está conectada (Figura 2).

Figura 2 - Modelo do geossistema de Bertrand.

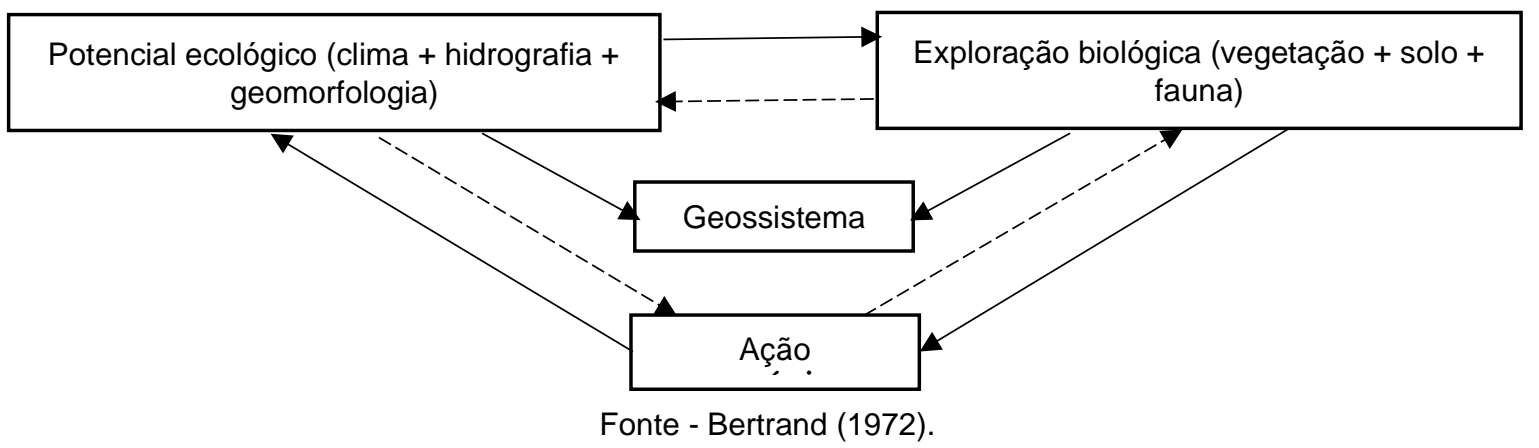

O método geossistêmico é um instrumento para análise integrada das paisagens. A categoria paisagem, adotada neste artigo, é uma das categorias chaves empregadas pela Geografia. Para o estudo na área pesquisada, utilizou-se como procedimentos metodológicos a pesquisa bibliográfica e documental, o levantamento cartográfico, o tratamento e as confecções de mapas físico-ambientais, a coleta e a interpretação visual de imagens orbitais.

Para o tratamento dos dados cartográficos e elaboração dos mapas foi utilizado o software livre Qgis versão 2.18.14-12. Assim, a partir do decreto nํㅜ 12.486 de criação do PESMA e do decreto nํ 12.487

1 SOTCHAVA, V. B. Introdución a la teoria de los geossistemas. Novo Sibersk: Nauka, 1963. 318 p.

2 Essa versão do software Qgis, assim como outras, pode ser adquirida gratuitamente por meio do site: https://www.qgis.org/pt_BR/site/forusers/download.html. 
de criação do RVSSMA, coletou-se as coordenadas geográficas que, posteriormente, foram inseridas como arquivo de texto (.txt) no software Qgis, compondo as bases cartográficas vetoriais do Parque, do Refúgio e de suas Zonas de Amortecimento (ZAs), no sistema de referência SIRGAS2000. Optouse pela base correspondente ao Refúgio por entender que esta engloba o Parque, sua Zona de Amortecimento $(\mathrm{ZA})$, assim como o Refúgio, pois a área deste último corresponde à área da ZA do Parque.

Adquiriu-se bases cartográficas da vegetação, da geologia e da pedologia do Brasil no site do Instituto Brasileiro de Geografia e Estatística (IBGE) do ano-base 2018; climas do Brasil no site do IBGE do anobase 2017; relevos brasileiros no site do Ministério do Meio Ambiente (MMA) do ano-base 2002; e a região hidrográfica do São Francisco no site da Agência Nacional de Águas (ANA) do ano-base 2017.

Uma vez obtidas essas bases cartográficas vetoriais, realizou-se o procedimento de intersecção com uso das ferramentas de geoprocessamento, cruzando-as com a base do Refúgio. A seguir, inseriu-se a base cartográfica da Bahia obtida no site da Superintendência de Estudos Econômicos e Sociais da Bahia (SEI) do ano-base 2017, fez-se ajustes na nomenclatura, espessura, contornos e coloração, usando cores distintas a fim de destacar os itens, concluindo o mapeamento no layout de página, tendo como resultado os mapas de vegetação, geologia, pedologia, clima, geomorfologia e hidrografia da área pesquisada.

As cores adotadas no mapa pedológico baseiam-se no Sistema Brasileiro de Classificação de Solos da Empresa Brasileira de Pesquisa Agropecuária (EMBRAPA, 2018), a seleção de cores para o fenômeno representado no mapa geomorfológico realizou-se sob orientação do Manual Técnico de Geomorfologia (IBGE, 2009) e, para os demais mapas optou-se por cores convencionalmente utilizadas. No mapa hidrográfico fez-se realce dos cursos d'água e uso de coordenadas cedidas pelo guia do Parque coletadas através do Sistema de Posicionamento Global por Satélite (GPS - Global Positioning System). Assim, foi preciso convertê-las de grau, minutos, segundos para o sistema decimal antes de inseri-las no software Qgis por meio de arquivo de texto (.txt).

Quanto ao mapa de hipsometria, buscou-se no site da EMBRAPA a carta topográfica SD-23-Z-B, com escala 1:250.000, em formato GEOTIFF (16 bits) e resolução espacial de 90 metros do ano-base 2015, adquirida pela missão Shuttle Radar Topography Mission (SRTM) ${ }^{3}$. Logo, inseriu-se no software Qgis a carta e a base geométrica do Refúgio e fez-se o recorte. Realizou-se ajustes nas cores e extraiu-se as curvas de nível. Por fim, adicionou-se a base da Bahia e concluiu a produção do mapa no layout de página.

Na verificação do uso do solo da SMA, foram utilizadas cenas orbitais do Google Earth ${ }^{4}$ e sobre elas, sobrepôs-se a delimitação vetorial do Parque (formato Keyhole Markup Language - KML) exportadas do software Qgis. Destacou-se algumas áreas com interpretação visual, que permitiram observar alterações antes e depois da criação das UCs.

\section{RESULTADOS E DISCUSSÃO}

\section{Aspectos geoambientais da Serra de Monte Alto}

A área pesquisada compreende partes do município de Candiba, Pindaí, Guanambi, Sebastião Laranjeiras, Urandi e Palmas de Monte Alto, e cartograficamente no sistema Universal Transversa de Mercator (UTM), está numa parte da folha SD 23-X-D. A caracterização geoambiental baseou-se no RADAMBRASIL ${ }^{5}$, projeto de mapeamento que inicia na Amazônia e arredores na década de 1970, sendo posteriormente expandido para todo o território brasileiro (MME, 1982).

Como meio de espacializar os dados geoambientais que caracterizam a área, foram produzidos sete mapas temáticos com extensão territorial correspondente ao Refúgio de Vida Silvestre da Serra dos Montes Altos (RVSSMA), a qual compreende o Parque da Serra dos Montes Altos (PESMA) e sua Zona de Amortecimento (ZA). Em virtude de fazer uso de fontes diferentes às utilizadas no texto, em alguns casos, as informações não coincidem com as representações espaciais. Isso, porém, não invalida nenhum dos meios empregados.

A área pesquisada compreende geologicamente às unidades litoestatigráficas do Complexo Santa Isabel, Suíte Monzonítico-Sienítica Guanambi, Supergrupo Espinhaço Indiviso, Formação Jequitaí e

\footnotetext{
${ }^{3} \mathrm{O}$ acesso pode ser feito pelo link: https://www.embrapa.br/en/satelites-de-monitoramento/missoes/srtm.

${ }^{4} \mathrm{O}$ Google Earth pode ser acessado baixando o aplicativo ou via web pelo link: https://www.google.com.br/intl/ptPT/earth/.

5 Projeto pioneiro no Brasil que surge com o objetivo de fazer levantamentos dos recursos naturais através de sensoriamento remoto. Fez-se a cobertura da área com aquisição de imagens orbitais da superfície terrestre, detalhando geologia, geomorfologia, pedologia, vegetação, entre outros aspectos (MME, 1982).
}

Caminhos de Geografia Uberlândia-MG $\quad$ v. 22, n. 81 jun./2021 $\quad$ p. 150-165 Página 153


Coberturas detríticas (TASSO, 2012). Na Serra de Monte Alto (SMA) encontra-se pequenos afloramentos do Complexo Santa Isabel, unidade geológica que abriga rochas ${ }^{6}$ do embasamento cristalino, cujas estruturas são polimetamórficas e tem origem no Arqueano, período da Era Arqueozoica composto pelos mais antigos terrenos da Terra. Já o Complexo de Guanambi apresenta rochas raras e comuns, maciças ou foliadas, do tipo porfiródica, cataclasada e/ou gnaissificadas. Prioritariamente leococráticas, são formadas por minerais de tonalidade clara ou esbranquiçada e masocrática, com coloração intermediária (MME, 1982; GUERRA e GUERRA, 2015).

Perante tais unidades certas peculiaridades se manifestam na região, que é rica em diversidade de rochas oriundas de períodos distintos da história geológica da Terra. Verifica-se a presença de granitos, rochas magmáticas que datam do "[...] Paleoproterozoico ${ }^{7}$, seguidos por eventos de sedimentação plataformal e estabilização crustal da Plataforma Sul-Americana, ao final do Neoproterozoico ${ }^{8}[\ldots]$ (TASSO, 2012, p. 30). Acredita-se que durante a formação dos continentes parte da Plataforma SulAmericana era interligada com o Supercontinente Atlântica e que nesse período tenha ocorrido o processo de separação.

A área é recoberta com sedimentos do Terciário ${ }^{9}$ e do Quaternário ${ }^{10}$, períodos da Era Cenozóica. Sendo evidente ainda blocos de quartzito com intercalações de metapelito pertencentes ao Subgrupo Espinhaço Indiviso (TASSO, 2012). Observa-se na Figura 3 os aspectos geológicos presentes na área pesquisada:

Figura 3 - Mapeamento da geologia do PESMA e RVSSMA, 2019.

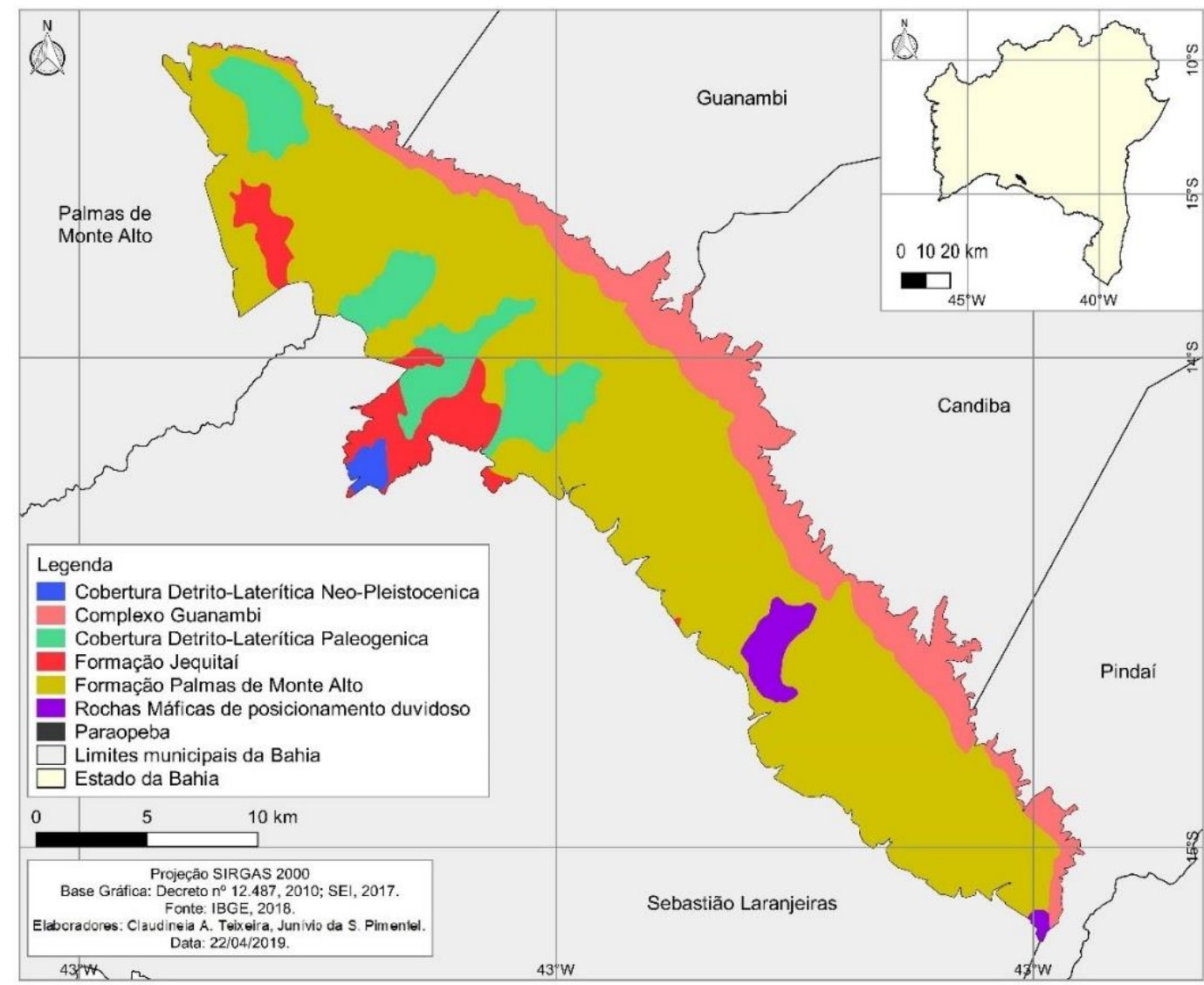

Fonte - Elaborado pelos autores com base em IBGE (2018), abril de 2019.

\footnotetext{
${ }^{6}$ Rochas são uma espécie de agregado natural composto por um ou mais minerais, sendo parte importante na constituição da crosta terrestre (LEINZ, 1989).

7 Trata-se da última era do éon proterozóico, anterior ao Cambriano. As rochas descritas datam de 2,5 a 1,6 bilhões de anos, mesmo período de surgimento dos primeiros seres eucariontes (BRANCO, 2016).

${ }^{8}$ É a primeira era do éon proterozóico, entre 1 bilhão e 542 milhões de anos atrás (BRANCO, 2016).

9 É o período da era Cenozóica visto como a idade dos mamíferos pelo seu grande desenvolvimento e marca o fim de grandes répteis dominadores do período anterior (GUERRA e GUERRA, 2015).

${ }^{10}$ É a última divisão do tempo geológico da Terra. Inicia há cerca de 2 milhões de anos e prossegue até os dias atuais (GUERRA e GUERRA, 2015).
} 
No que se refere à geomorfologia, a área compreende a estrutura geomorfológica do Pediplano Sertanejo, Serras Centrais do Planalto Espinhaço e Depressão do São Francisco-Rio de Contas. Esta última, segundo Barbosa, Boaventura e Pinto (1973) apud MME (1982), é composta por três unidades geomorfológicas: Vão do São Francisco, Pediplano Sertanejo e Patamares do Médio Rio de Contas. O Vão do São Francisco, cujo relevo se caracteriza por aplanamentos que se iniciam nas escarpas e Patamares Orientais e Ocidentais do Espinhaço, é marcado pela presença de relevos residuais (Figura 4).

Figura 4 - Mapeamento da geomorfologia do PESMA e RVSSMA, 2019.

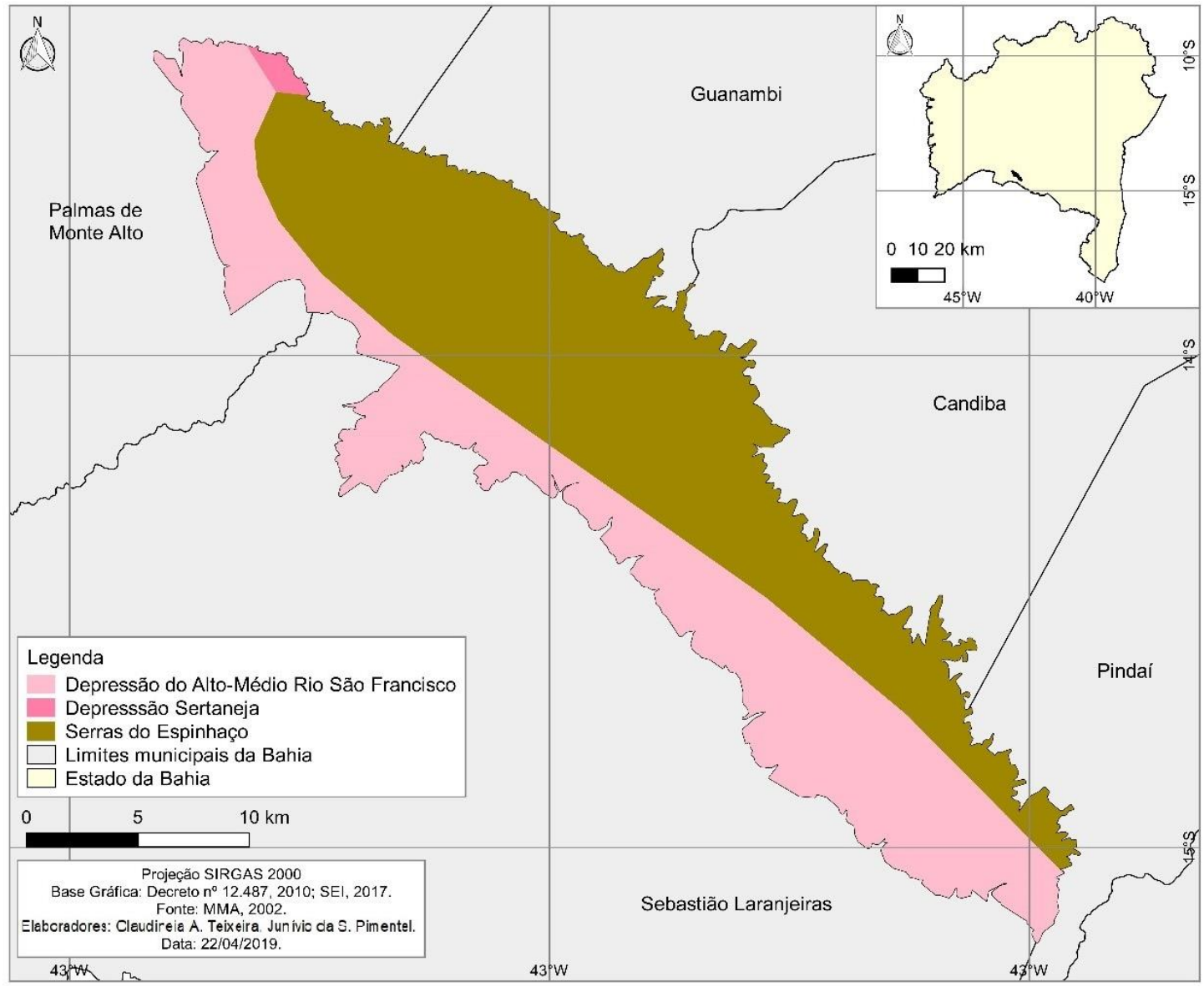

Fonte - Elaborado pelos autores com base MMA (2002), abril de 2019.

No Vão do São Francisco, têm-se inselbergs ${ }^{11}$ cortados pelas planícies fluviais do médio São Francisco, geralmente com altitude acima de 100 metros. Com efeito, a região se individualiza pela presença de extensos planos inclinados sob o embasamento cristalino e do grupo Bambuí. Por ser pouco dissecado e em razão de aspectos do clima com influência direta nas chuvas e hidrografia, essa área não tem atuação expressiva de agentes erosivos (MME, 1982).

Em direção ao norte, percorrendo o rio São Francisco na Serra de Monte Alto, estabelece-se a unidade geomorfológica do Pediplano Sertanejo com o relevo dissecado dos patamares do Espinhaço. Nesse ponto, sobressaem proeminências topográficas que se apresentam em bom estado de conservação por causa da presença de cangas, um termo regional usado para designar concreções ou crostas ferruginosas (MME, 1982).

O Pediplano Sertanejo está incluído em parte no domínio das depressões pediplanadas e alcança altitudes de médias a alta. Formado por planos inclinados com cobertura de material coluvial, cujas

11 Inselbergs "[...] são elevações que aparecem em regiões de clima semiárido. São como resíduos da pediplanação, em climas quentes, áridos e semiáridos, à semelhança dos monadnocks, devido à pediplanação em regiões de clima úmido" (GUERRA e GUERRA, 2015, p. 353). 
oscilações têm em média cerca de cinco graus, tal composição do relevo leva a ocorrência de ravinas, curvas sinuosas e caminhos vistos no terreno (MME, 1982).

A Serra de Monte Alto integra o conjunto de serras que formam as Serras Centrais, uma das divisões do Planalto do Espinhaço. Com dissecação diferencial e drenagem profunda, que varia entre 50 e 195 metros, esta unidade geomorfológica distingue-se pela sobreposição de aspectos aparentemente ligados à tectônica que condicionou a existência de um deslocamento inverso para Oeste no terreno, os quais se juntam aos efeitos de falhamento perpendicular e oblíquo (MME, 1982; GUERRA e GUERRA, 2015).

A Serra de Monte Alto apresenta feições monoclinais, isto é, a estrutura das camadas inclina-se em apenas uma direção. O relevo de estrutura cuestiforme apresenta uma inclinação topográfica de cerca de 10 graus em direção ao Sudoeste conforme mergulho das camadas. Diante deste, estabelece aclives de topo plano encaixado a falha em forma de escada, situada a pré-cristas da Serra do Espinhaço (MME, 1982; GUERRA e GUERRA, 2015). Segundo Tasso (2012, p. 33), esse alinhamento do relevo na SMA favorece o "[...] escoamento superficial neste sentido, que alimenta várias nascentes como as pertencentes ao rio Casa Velha e aos riachos Mandiroba e Aguapé".

A área pesquisada apresenta superfícies com níveis altimétricos variados, resultando em algumas classes hipsométricas representadas na Figura 5, que traz a quantificação das curvas de nível, cuja equidistância das isolinhas delimitada foi 80 metros de altitude.

Figura 5 - Mapeamento da hipsometria do PESMA e RVSSMA, 2019.

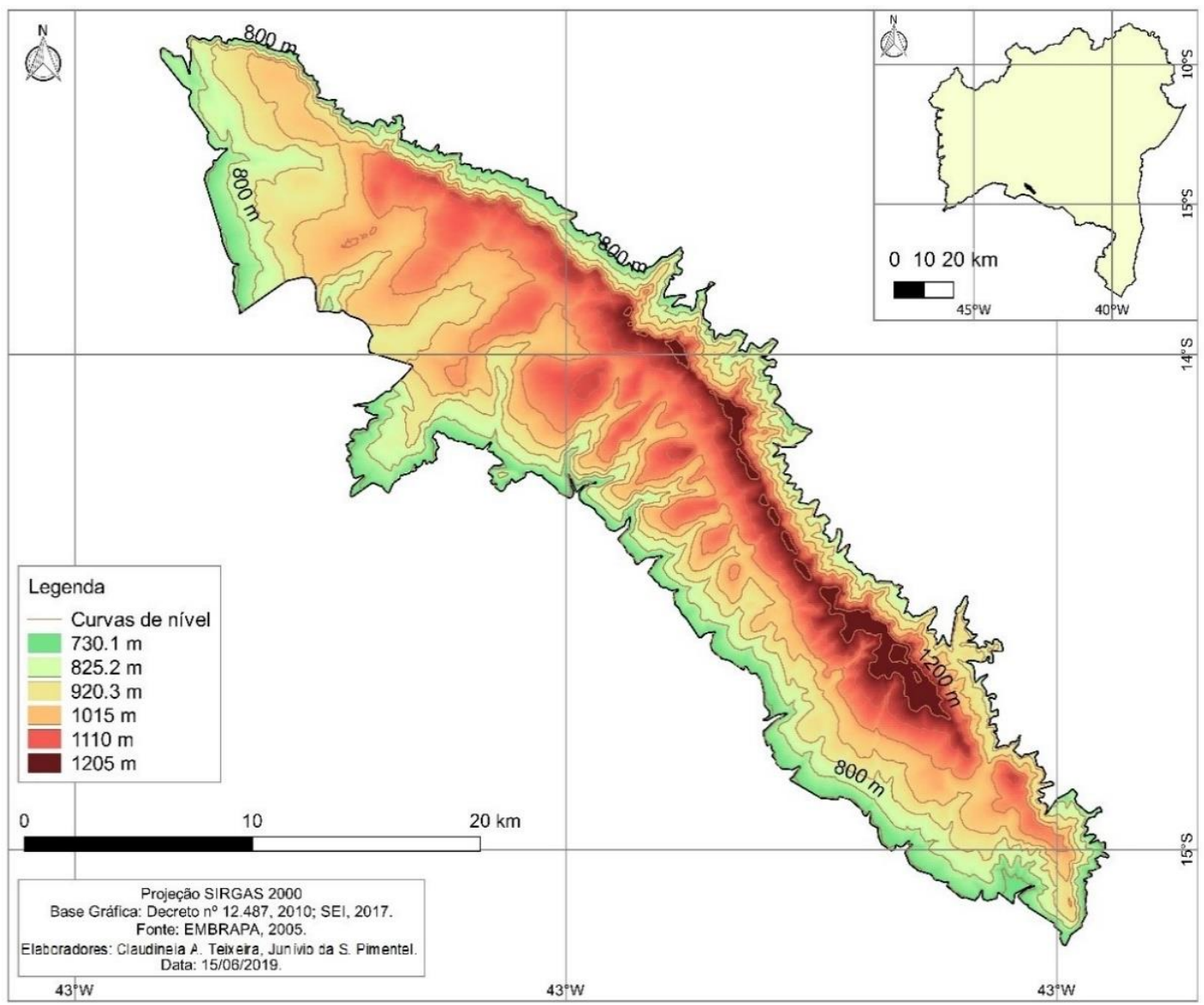

Fonte - Elaborado pelos autores com base em EMBRAPA (2005), abril de 2019.

Verifica-se que os pontos menos elevados do terreno localizam na periferia da área com cotas altimétricas em torno de 730 metros, enquanto os locais de maior elevação correspondentes ao topo da Serra registram cerca de 1.200 metros de altitude. Essa alta declividade das vertentes faz com que as águas pluviais e fluviais ganhem força e velocidade ao descer o relevo acidentado da SMA. 
Em conformidade com Oliveira e Bernardes (2018), a Serra apresenta duas vertentes. Por um lado, possui uma vertente com escarpa abrupta e alta altitude que se estabelece entre 950 a 1.260 metros. Ao mesmo tempo, no sentido Noroeste-Sudeste, a outra vertente mostra-se suave, com topo plano e leves inclinações. Ela é retilínea, com certo alinhamento que é definido por falha, a qual pode ser verificada nos afloramentos presentes em áreas limitantes entre os municípios Palmas de Monte Alto e Sebastião Laranjeiras.

Caracterizando a área pesquisada o clima classifica-se predominantemente como semiárido, com parte do tipo semiúmido. O primeiro proporciona chuvas de novembro a março, com o restante dos meses secos e índices pluviométricos baixos, em torno de 10 milímetros. O mês que registra os maiores índices pluviométricos é dezembro, sendo que o regime anual registra máximo com cerca de 1.340 milímetros, médio em torno de 694 milímetros e mínimo correspondente a 227 milímetros. A temperatura tem máxima de $28,6^{\circ} \mathrm{C}$, média de $22,6^{\circ} \mathrm{C}$ e mínima de $18,5^{\circ} \mathrm{C}$ (RODRIGUES, 2012).

Já o tipo climático semiúmido aparece na Serra sob a influência do relevo, o qual, esculpido externamente sobretudo pelo escoamento superficial das águas pluviais e fluviais, favorece a ocorrência de chuvas orográficas. É ameno, possui precipitação registrada em torno de 800 a 1.000 milímetros anuais (SANCHES e BERNARDES, 2012). (Figura 6).

Figura 6 - Mapeamento do clima do PESMA e RVSSMA, 2019.

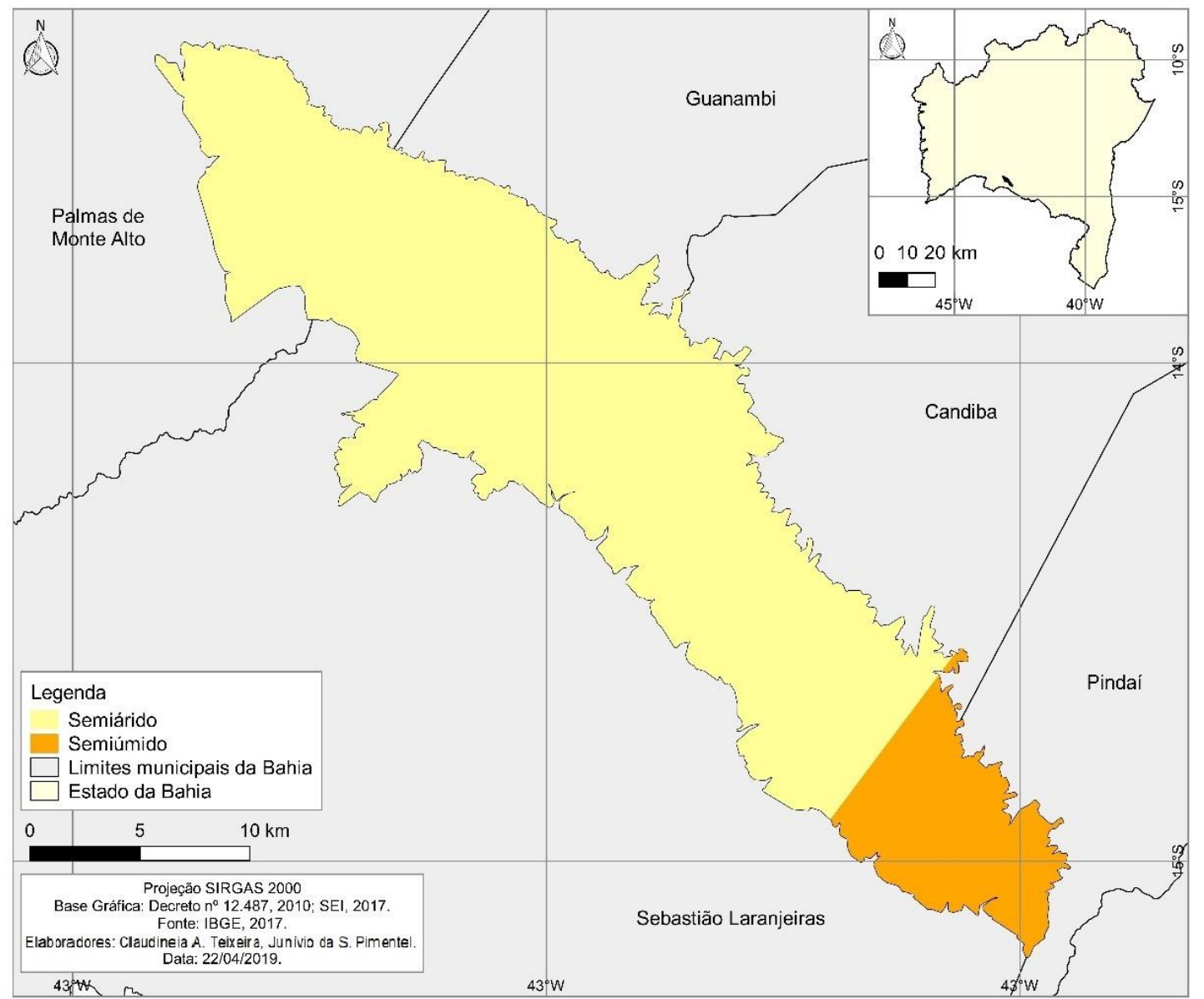

Fonte - Elaborado pelos autores com base em IBGE (2017), abril de 2019.

Em relação aos aspectos pedológicos, a área pesquisada apresenta predominantemente solos das classes Cambissolos Eutróficos, Neossolos Eutróficos, Espodossolos Eutróficos e Latossolos Vermelho-Amarelos Distróficos, Eutróficos e Álicos (TASSO, 2012). Os Espodossolos apresentam nítida diferenciação entre seus horizontes e são compostos com acúmulo de matéria orgânica e/ou alumínio e ferro (EMBRAPA, 2018, s/p). Conforme o MME (1982) na SMA os Latossolos VermelhoAmarelos Álicos apresentam alto índice de acidez. Os solos Cambissolos Eutróficos possuem textura

Caminhos de Geografia $\quad$ Uberlândia-MG $\quad$ v. 22, n. $81 \quad$ jun./2021 $\quad$ p. 150-165 Página 157


argilosa, variando de baixa a alta proporção. São pouco drenados ou possuem drenagem elevada, sendo suscetíveis a erosões. (Figura 7).

Figura 7 - Mapeamento dos aspectos pedológicos do PESMA e RVSSMA, 2019.

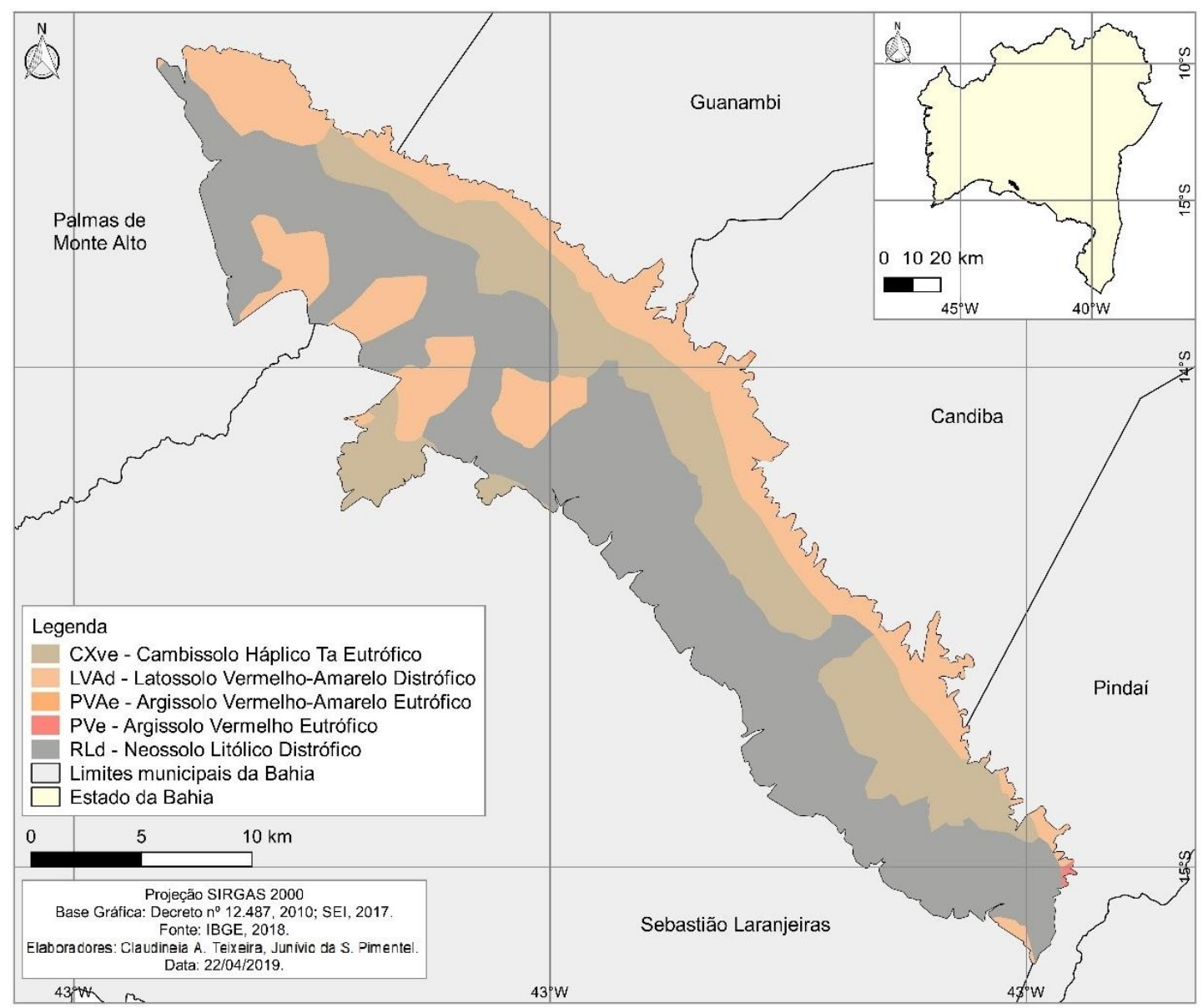

Fonte - Elaborado pelos autores com base em IBGE (2018), abril de 2019.

Na Figura 7 há em menor proporção os solos Argissolo Vermelho Eutrófico e Argissolo VermelhoAmarelo Eutrófico. Conforme EMBRAPA (2018) os Argissolos são solos profundos, compostos basicamente por material mineral com acúmulo de argila em sua subsuperfície de baixa ou alta atividade conjugada ao caráter alumínico. Os Latossolos são altamente desenvolvidos e profundos, com elevado processo de ferralitização. Essas duas classes de solo ocorrem geralmente em ambiente úmido, sendo, deste modo, encontradas na área estudada mais frequente no setor de clima semiúmido, em partes cujo modelado do relevo favorece a infiltração e a pedogênese.

As classes Cambissolos e Neossolos são formadas por solos jovens, poucos profundos, sendo a primeira considerada moderadamente desenvolvida e a segunda, com pouco desenvolvimento preserva características do material de origem (EMBRAPA, 2018). Diante disso, os Cambissolos e Neossolos se desenvolvem na SMA em pontos onde o índice de precipitação é menor e o relevo facilita o escoamento superficial e a morfogênese.

Com forte influência da altitude, a vegetação presente na área pesquisada está compreendida dentro do bioma do Cerrado e da Caatinga. Encontra-se a partir do ponto de menor elevação às médias altitudes (em torno de 960 metros) espécies típicas da Caatinga. Daí em diante até as altas altitudes, a Serra é coberta por vegetação correspondente ao Cerrado, sendo exemplo pequizeiros, cactáceas, palmáceas e plantas frutíferas que servem de alimento a sua fauna diversificada como répteis, mamíferos e aves. Nas maiores elevações predomina a vegetação do tipo Floresta Tropical Decídua típica de regiões que apresentam duas estações climáticas bem demarcadas, uma seca e outra chuvosa (TASSO, 2012). 
A Caatinga presente em parte do território brasileiro é composta por vegetação decidual, lenhosa com composição florística diversificada (MME, 1982). Tal vegetação é típica de climas que apresentam certo grau de semiaridez, posto que segundo Ab'Saber (2003, p. 85-86), "[...] até onde vão as diferentes fáceis da Caatinga de modo relativamente contínuo, estaremos na presença de ambientes semiáridos $[\ldots] "$.

Conforme Ab'Sáber (2003) no domínio da Caatinga existe variabilidade climática, destarte, a temporada de chuva não chega algumas vezes no tempo estimado, prolongando o período de estiagem. As plantas se adaptaram a essas condições climáticas, assim, em períodos de estiagem, tendem a secar. Entretanto, ao cair as primeiras gotas de chuva, árvores e arbustos com folhas pequenas e diversos espinhos protetores intercalados por cactáceas cobertas de poeira recuperam o verde e a exuberância. Então, as águas presentes na superfície do solo, em conjunto com a alta luminosidade, revitalizam os processos da fotossíntese.

A vegetação do Cerrado tem composição florística diversificada e é sujeita à sazonalidade climática. Trata-se de plantas adaptáveis e resistentes que não necessitam de grande quantidade de nutrientes, pois "[...] não existe comunidade biológica mais flexível e dotada de poder de sobrevivência em solos pobres do que os Cerrados" (AB'SÁBER, 2003, P. 125). Em uma escala paisagística o domínio do Cerrado brasileiro pode se apresentar como cerrado, cerradões e campestres. A vegetação do tipo Cerrado da região é formada por plantas arbóreas e arbustivas com caules tortos, casca grossa, folhas coriáceas e brilhantes ou revestidas densamente por conjunto de pelos, sendo geralmente de pequeno porte e associada a solos arenosos ou a áreas rupestres (RODRIGUES, 2012).

$\mathrm{Na}$ Serra, a vegetação de pequeno porte, incluindo ervas e arbustos se manifesta em zonas pedregosas de solos rasos e lajedos e, associadas a topos de serra, tem potencial para endemismo. Na encosta oeste de áreas de alta altitude é frequente floresta do tipo seca associada à vegetação de ripária, cuja maioria é também de pequeno porte (SOARES FILHO, HARLEY e SOUZA, 2012), Figura 8.

Figura 8 - Mapeamento da vegetação do PESMA e RVSSMA, 2019.

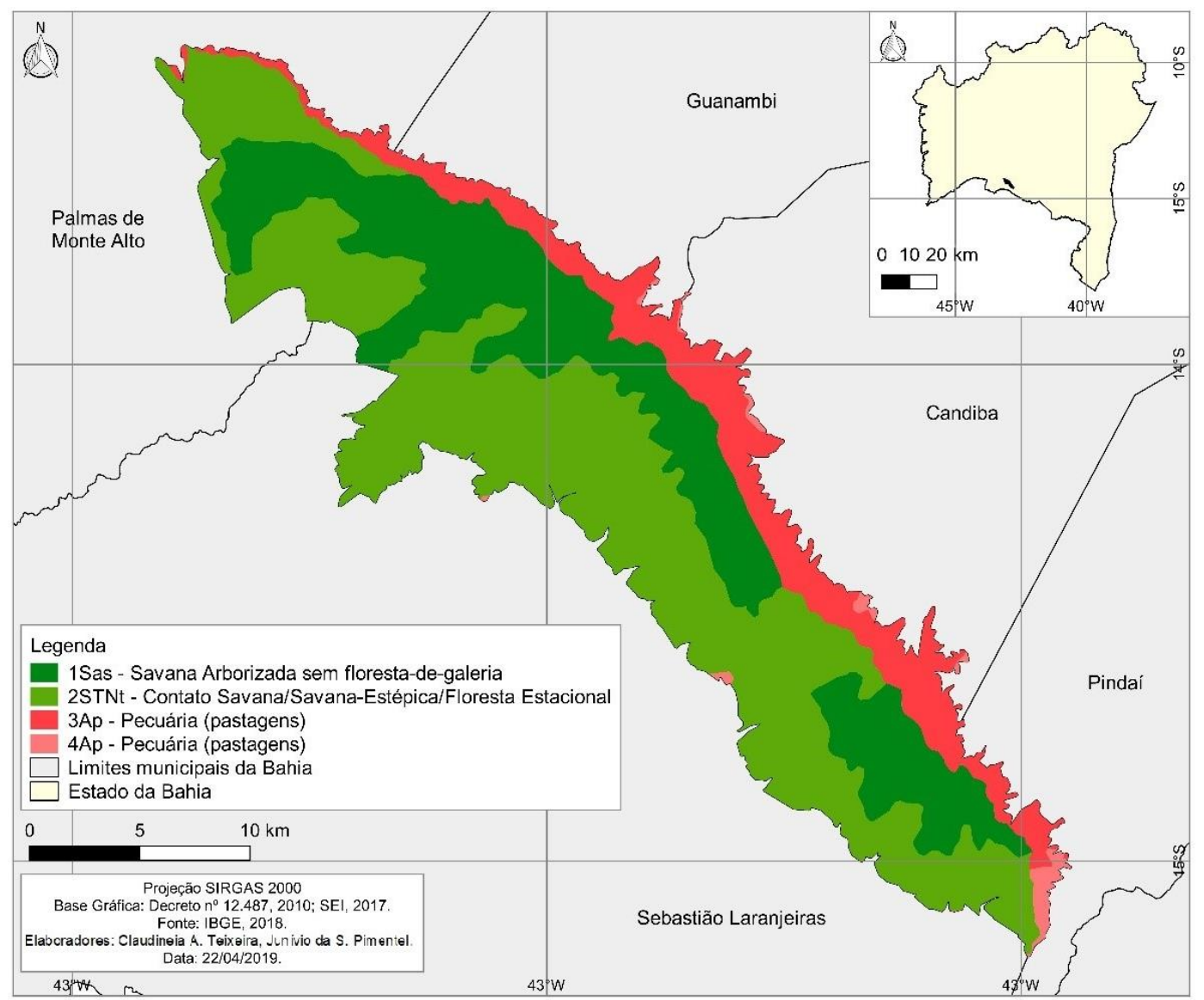

Fonte - Elaborado pelos autores com base em IBGE (2018), abril de 2019. 
São comuns na área espécies frutíferas silvestres como Canjirama (Cabralea canjerana) e pinha do mato (Annona crassiflora) em meio às matas de galeria, as quais são encontradas principalmente em boqueirões sobre solo arenoso ou leito rochoso, em riachos e rios. As matas de galeria apresentam-se espaçadas no terreno, sendo a maioria de médio porte, embora haja espécies pequenas misturadas à paisagem. Como exemplo, têm-se espécies de Angico (Anadenanthera colubrina) e Vinhático (Plathymenia foliolosa). Além disso, existem plantas típicas de charcos ou brejos, áreas alagadas temporariamente ou permanentemente durante o ano (SOARES FILHO, HARLEY e SOUZA, 2012).

Em relação à dinâmica hídrica, a área abrange águas superficiais e subterrâneas que ajuda compor a dinâmica hídrica regional. A abundância do recurso natural água oriundo da SMA tem valor significativo, sobretudo, para a população local já que é necessário em seu consumo diário e no desenvolvimento de atividades de subsistência (RODRIGUES, 2012). Sua hidrografia compreende rios, riachos e nascentes, como exemplo as dos riachos Mandiroba e Aguapé, do rio Casa Velha ou Curralinho, como é também conhecido, bem como quedas d'água como as cachoeiras do Mandiroba, Brucunum, Cotandiba Poço do Buracão e Poço Azul (SANCHES e BERNARDES, 2012), Figura 9.

Figura 9 - Mapeamento da hidrografia do PESMA e RVSSMA, 2019.

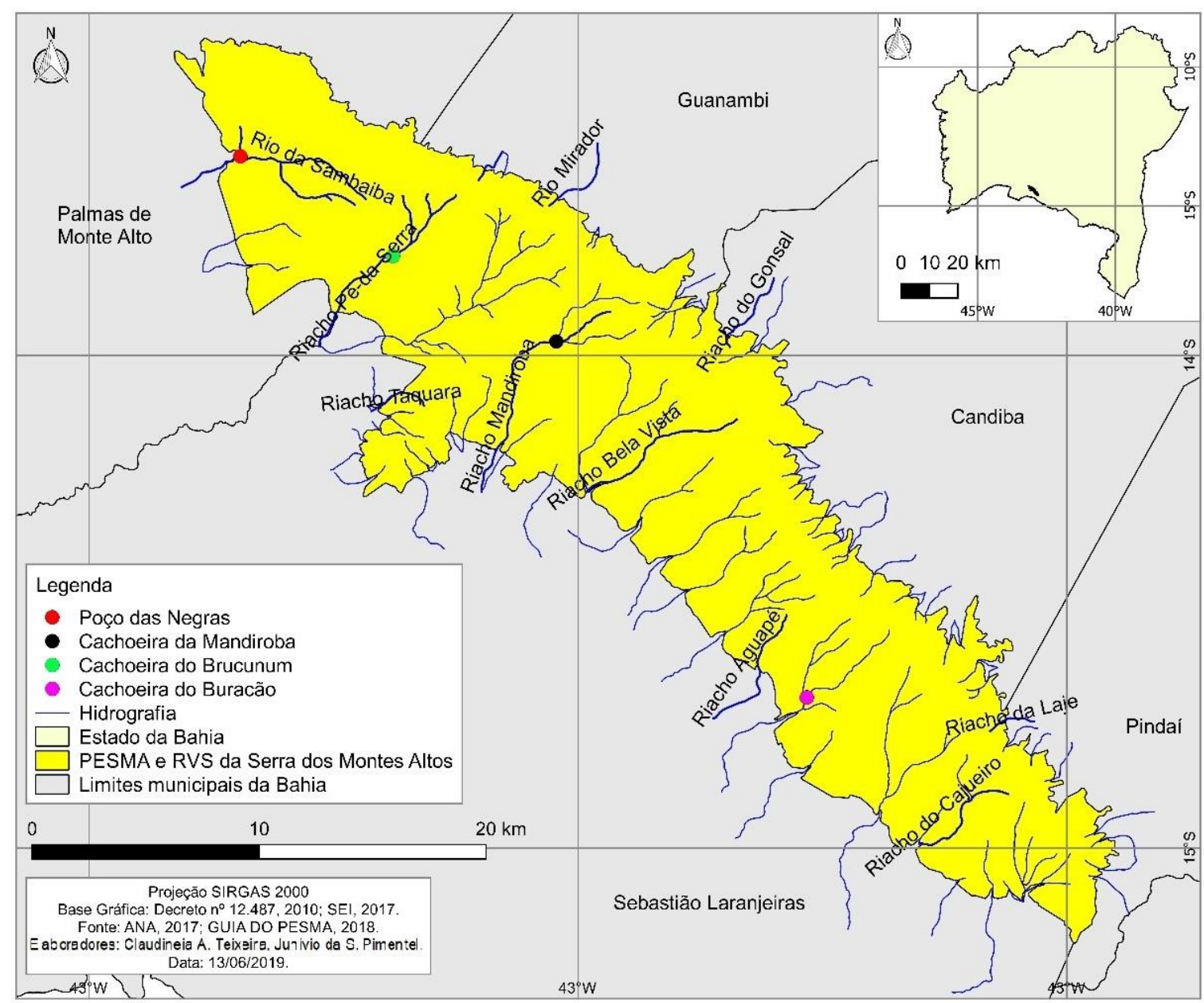

Fonte - Elaborado pelos autores com base em ANA (2017) e GUIA DO PESMA (2018), abril de 2019.

Os cursos d'água da área pesquisada nascem em pontos elevados na Serra, rodeados pela vegetação a média distância de comunidades locais. Suas características, como vasão e fluxo de água, são influenciadas pelo clima e relevo, e em contrapartida, atuam influenciando a vegetação, solo e rochas. Segundo Rodrigues (2012) a SMA abriga cursos perenes e intermitentes dos respectivos municípios que a compreende, a exemplo dos rios Mandiroba e Curral de Pedras pertencentes à bacia do rio Verde Grande, o qual posteriormente deságua no rio São Francisco. Além disso, existe variedade de riachos efêmeros pertencentes à bacia do rio Carnaíba, afluente à margem direita do rio São Francisco.

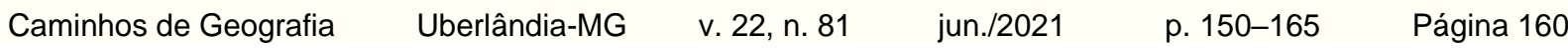


Os rios de fluxo intermitente presentes na área possuem relação de dependência com o ritmo pluviométrico, tendo maior quantidade de água em seu leito na estação chuvosa. Contudo, de acordo com Ab'Sáber (2003), diferentemente de outras regiões semiáridas, apesar de muitos rios da Região Nordeste do Brasil serem intermitentes todos em algum momento no ano conseguem chegar ao mar, no oceano Atlântico.

Todas essas diferentes características da paisagem na área estudada proporcionam a criação de dinâmica ambiental diferenciada, cujos formatos se assemelham à configuração de uma ilha. Enquanto a ilha é cercada por água tendo no seu interior área de terra, a SMA é circundada pelo bioma da Caatinga, que se estabelece ao redor da parte central onde o bioma do Cerrado prevalece e se faz presente, das médias às altas altitude. $\mathrm{E}$ no intermédio dessas duas áreas, encontra-se a vegetação de transição Caatinga-Cerrado.

Essa configuração distinta faz com que a área ganhe evidência na paisagem regional. Por outro lado, a riqueza em recursos naturais desperta interesses econômicos que podem culminar em ações que levem a prejuízos para sua dinâmica ambiental. Rodrigues (2012) afirma que na SMA foram verificadas práticas degradantes a exemplo da criação de gado bovino, mineração de granito, práticas agrícolas, queimadas e desmatamentos ilegais, ocasionando, alterações em seu ecossistema.

Tendo em vista que na área cada componente tem função e importância para a manutenção da dinâmica ambiental, já que é a integração deles que compõem as paisagens terrestres essas práticas são preocupantes. Tanto a geologia, como a geomorfologia, o clima, a pedologia, a vegetação, a hidrografia e a fauna dependem e se inter-relacionam no que tange ao processo de formação, e no desenvolver de suas configurações da área, destarte, a conservação de cada elemento é necessária, porque qualquer alteração poderá levar a uma situação de desiquilíbrio que afetará o meio ambiente local, acarretando em consequências para áreas adjacentes.

\section{Uso do solo por meio de imagens do Google Earth}

As geotecnologias estão presentes na atualidade, ganhando cada dia mais espaço e adeptos. Apesar de seu potencial para estudos geográficos ainda não ter sido explorado por completo, elas vêm servindo às ciências e ao vasto campo do conhecimento humano, bem como em outros setores da sociedade (FLORENZANO, 2005).

Os sensores remotos instalados em satélites espaciais ou outros meios operam em várias regiões do espectro eletromagnético, do visível a micro-ondas, podendo ser de baixa, média, alta ou altíssima resolução. Conforme Florenzano (2002) as imagens obtidas com o sensoriamento remoto permitem visualização em conjunto dos objetos na superfície terrestre, podendo abranger pequenas ou grandes áreas. Essa visão multitemporal das paisagens é valiosa para estudos geográficos porque mostra a evolução no tempo e no espaço dos fenômenos naturais e/ou antrópicos. Além disso, essa geotecnologia permite coletar informações em áreas de difícil acesso de forma confiável, com precisão, agilidade e periodicidade.

A visualização de imagens orbitais pode ser obtida gratuitamente em plataformas digitais como Google ${ }^{12}$, Bing ${ }^{13}$, Here $^{14}$ etc. Apesar da qualidade das imagens não serem idênticas à dos satélites de monitoramento ambiental, essas apresentam geometria, equalização, resolução espacial, precisão geométrica e atualidade, fazendo desses provedores ferramentas viáveis para estudos geográficos qualitativos e exploratórios (SAUSEN e LACRUZ, 2015).

O livre acesso à visualização das imagens orbitais da área pesquisada permitiu comparar o uso do solo e a cobertura vegetal antes e após a criação do Parque da Serra dos Montes Altos. Para isso, utilizouse cenas do aplicativo Google Earth Pro ${ }^{15}$ provenientes dos anos 2009, 2010, 2018 e 2019.

$\mathrm{Na}$ Figura 10, visualiza-se a área pesquisada nos dias atuais, sendo observadas diferentes formas de uso do solo nas proximidades do Parque da Serra dos Montes Altos e Refúgio de Vida Silvestre da Serra dos Montes Altos. A área é circundada por atividades agrícolas e/ou agropecuárias, entre outros usos do solo, o que fortalece a importância da criação dessas UCs para a conservação da dinâmica ambiental da Serra de Monte Alto.

12 O link para acesso é: https://www.google.com.br/maps.

${ }^{13} \mathrm{O}$ acesso pode ser feito através do link: https://www.bing.com/maps.

${ }^{14} \mathrm{O}$ acesso pode ser feito pelo link: https://wego.here.com/?x=ep\&map=-13.9078,-42.5223,10, normal.

$15 \mathrm{O}$ download pode ser feito através do link: https://www.google.com.br/earth/download/gep/agree.html.

$\begin{array}{lllll}\text { Caminhos de Geografia } \quad \text { Uberlândia-MG } & \text { v. 22, n. } 81 \quad \text { jun./2021 } & \text { p. 150-165 } & \text { Página } 161\end{array}$


Figura 10 - Imagem orbital do PESMA e RVSSMA, 2019.

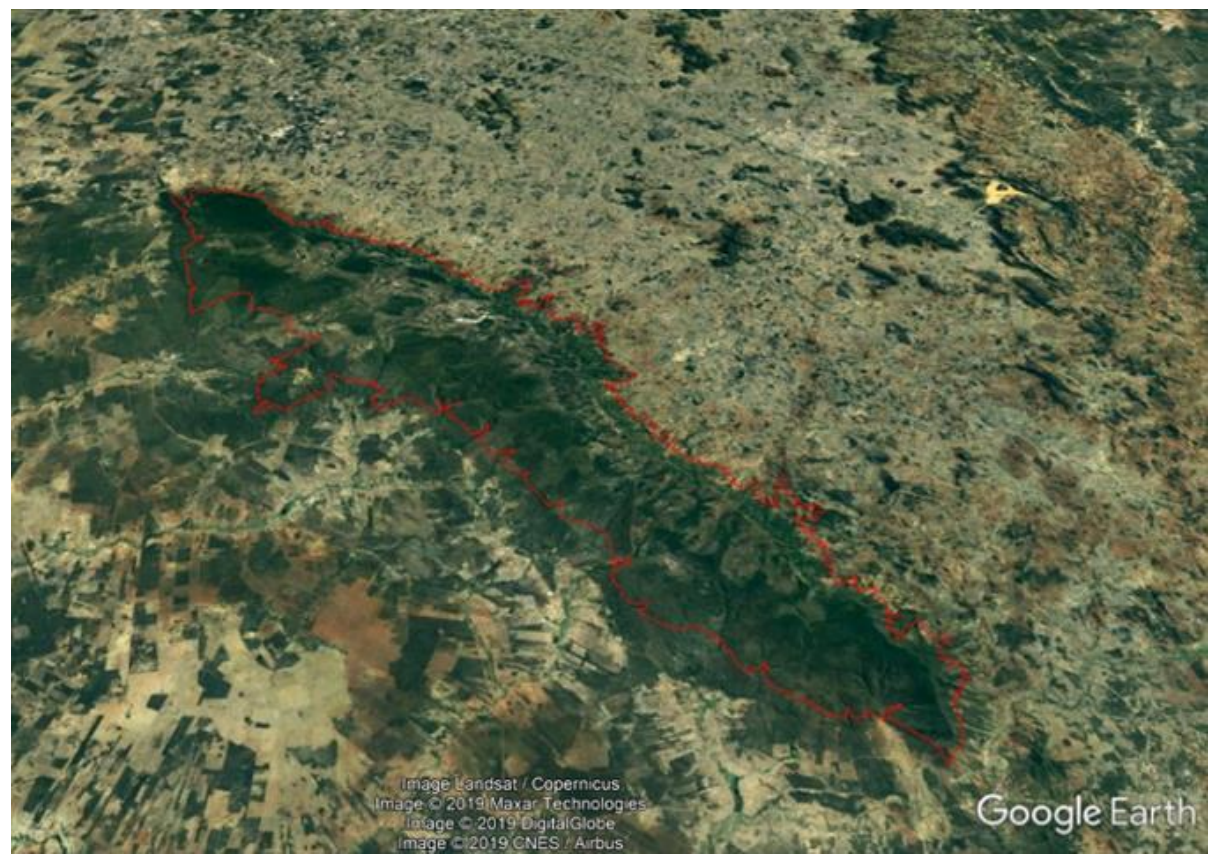

Fonte - Google Earth Pro (2019)

Na Figura 11, mais precisamente 2010 (A) e 2018 (A), consta-se diversidade no uso do solo, sendo perceptível a ampliação da área desmatada entre os anos de 2010 e 2018. Todavia, em outra área do Parque, no mesmo intervalo de tempo, as imagens 2010 (B) e 2018 (B) mostram aumento significativo de cobertura vegetal, revelando indícios de possível regeneração da vegetação nativa. Isso leva a crer que a criação do Parque no ano de 2010 possa ter contribuído para esse progresso.

Figura 11 - Conjunto de imagens orbitais do PESMA e RVSSMA, 2009, 2010, 2018, 2019.

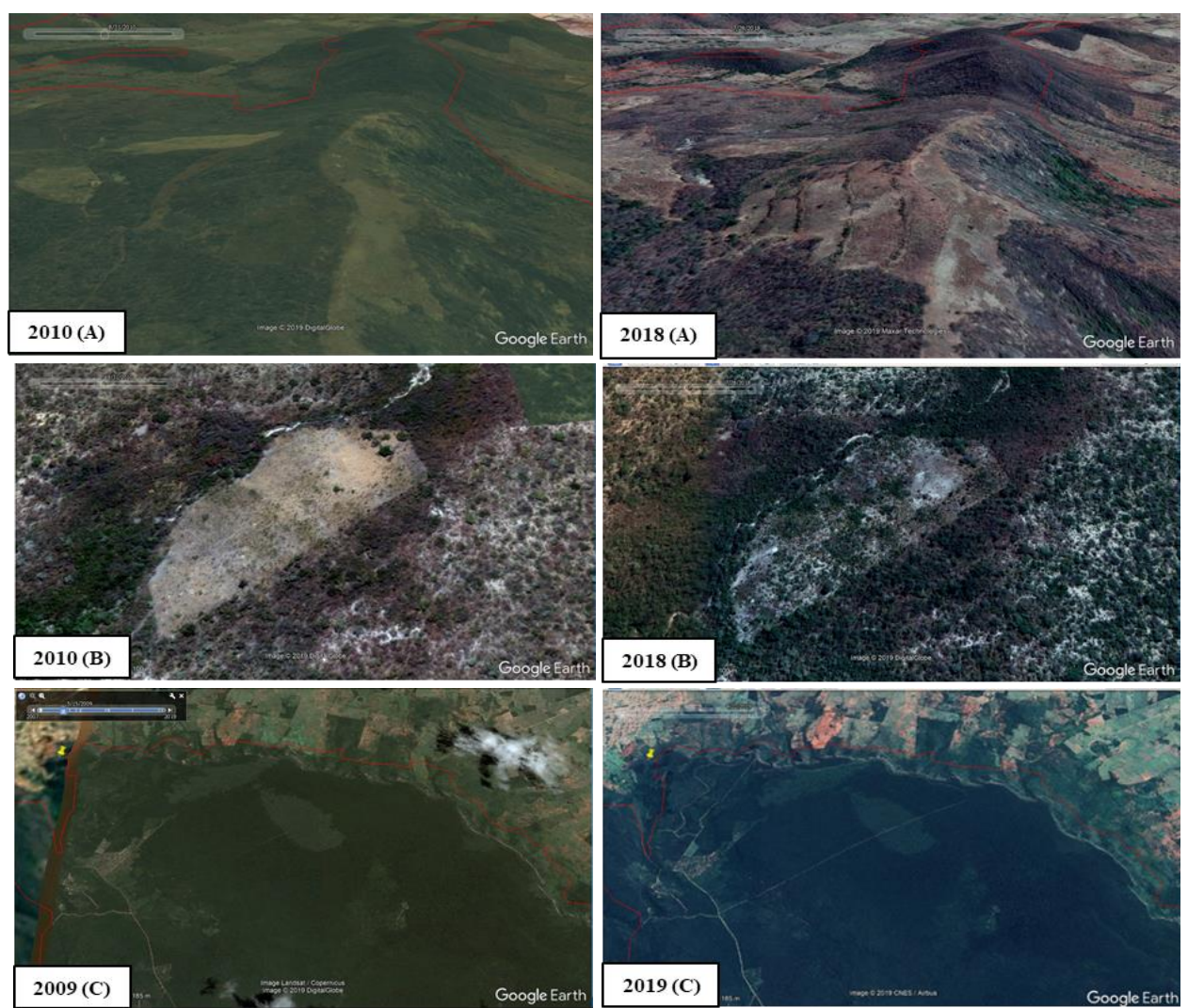

Fonte - Google Earth Pro (2009, 2010, 2018, 2019). 
Comparando as imagens 2009 (C) e 2019 (C) não é possível perceber alterações na vegetação, observa-se apenas o surgimento de caminhos ou estradas em meio às paisagens. Sinais de interferência humana que, todavia, pode não ser degradação e, sim, criados para facilitar o acesso a trilhas e/ou para deslocamento dos guardas do Parque que realizam o monitoramento com motocicletas.

A análise das imagens supracitadas evidenciou que em determinadas áreas do Parque, desde sua criação ao momento atual, não houve detecção de mudanças bruscas no estado da cobertura vegetal e uso do solo nas paisagens. Enquanto em determinados locais pode-se observar manchas de desmatamento. Portanto, num contexto geral, é possível afirmar que a criação do Parque e do Refúgio tem contribuído para preservar a biodiversidade existente neste espaço.

\section{CONSIDERAÇÕES FINAIS}

A Serra de Monte Alto apresenta paisagens marcantes que a destaca na região. A extensa área engloba parte de seis municípios da Bahia e conta com características geoambientais diferenciadas que foram representadas através de mapeamento. Os mapas espacializam seus aspectos e contribuem para entendimento de suas dinâmicas.

$\mathrm{Na}$ área foram criadas duas UCs, o Parque Estadual da Serra dos Montes Altos e o Refúgio de Vida Silvestre da Serra dos Montes Altos. O Parque destina-se à preservação e, além das riquezas ambientais, compreende patrimônio histórico com registros da presença de povos primitivos na região. Com cachoeiras e nascentes, exibe potencial para endemismo, pois sua fauna e flora apresentam características particulares.

A metodologia aplicada mostrou-se eficaz, levou ao alcance de resultados satisfatórios do ponto de vista técnico, científico e prático, contribuindo para assegurar o cumprimento dos objetivos propostos. A paisagem como categoria de análise aliada ao método geossistêmico foi ideal para leitura integrada dos elementos físicos, biológicos e antrópicos, sendo viável para verificação no tempo e espaço o estado de conservação e preservação das UCs.

Com a análise dos resultados constatou-se que existem locais dentro do Parque que foram alterados com retirada da cobertura vegetal anteriormente a criação das UCs, deixando o solo exposto e propício a sofrer erosão. Todavia, ao delimitar a área, criou-se ambiente favorável à sua recuperação, sendo notável em alguns locais a regeneração da vegetação.

Em áreas cuja vegetação não se regenerou integralmente pode haver sulcos e ravinas no solo. Apesar disso, o impacto da erosão na área pode ser classificado visualmente como baixo em razão da conservação da cobertura vegetal. Esse fato contribui para a manutenção da biodiversidade no Parque e Refúgio, a qual carece ser pesquisada de forma incisiva, pois estima-se que haja espécies não catalogadas, com potencial para endemismo.

Atualmente o Parque conta com poucos profissionais envolvidos na sua proteção, é pequeno o número de guardas diante da extensão territorial da área para fiscalização. Além disso, tem Conselho Gestor inativo e não dispõe de Plano de Manejo (PM). Entretanto, no próximo biênio tal problema deve ser resolvido com a elaboração do Plano para o PESMA e RVSSMA. Deve-se difundir os princípios adotados no Plano junto a população local e regional, bem como adotar gestão eficiente.

Seria igualmente interessante aproveitar a potencialidade para turismo das UCs e aliá-la a projetos de educação ambiental de forma a propiciar que as pessoas desfrutem de suas paisagens e belezas, ao passo que se conscientizam sobre a relevância da preservação. A ONG PRISMA que já atua amplamente na região na proteção das UCs poderia servir de apoio à realização destas ações.

A partir do estudo constatou-se que a criação do PESMA e RVSSMA teve impacto positivo para biodiversidade regional. A área passou a ser protegida, contribuindo para conservação e preservação de seu patrimônio ambiental e histórico. É fato que existem práticas degradantes que ainda não foram erradicadas como agropecuária e extração mineral, mas essas atividades passaram a ser monitoradas por fiscais do INEMA, o que impede alterações mais incisivas e/ou expansão.

Essas práticas degradantes talvez sejam reflexos da demora na criação do $P M$ e da não conscientização sobre os objetivos que estão por trás da criação das UCs. Portanto, é indispensável conscientizar e envolver a sociedade no tocante à proteção de seu patrimônio ambiental e histórico, entendendo e respeitando o vínculo construído ao longo do tempo com comunidades adjacentes. 
Assim, as UCs podem ser vistas como espaço para recreação, educação ambiental, pesquisa e manejo de recursos por meios de ações sustentáveis em concordância com as diretrizes do PM, podendo gerar benefícios econômicos e socioambientais para a região.

\section{REFERÊNCIAS}

AB'SÁBER, Aziz Nacib. Os domínios da natureza do Brasil: potencialidades paisagísticas. São Paulo: Ateliê Editorial, 2003.

BAHIA. Decreto o 12.486 de 29 de novembro de 2010. Cria o Parque Estadual da Serra dos Montes Altos, no Estado da Bahia, e dá outras providências. Salvador, BA, Palácio do Governo do Estado da Bahia, 29 de novembro de 2010a. Disponível em: http://www.oads.org.br/leis/2748. pdf. Acesso em: 4 nov. 2018.

Decreto ํㅜ 12.487 de 29 de novembro de 2010. Cria o Refúgio de Vida Silvestre da Serra dos Montes Altos, no Estado da Bahia, e dá outras providências. Salvador, BA, Palácio do Governo do Estado da Bahia, 29 de novembro de 2010b. Disponível em: http://oads.org.br/leis/2749. pdf. Acesso em: 4 nov. 2018.

Edital de Chamamento Público no 001/2018 acordos de cooperação. Seleção de organização da sociedade civil sem fins lucrativos interessada em celebrar Acordo de Cooperação cujo objeto é a execução de atividades decorrentes da Compensação Ambiental em sua modalidade indireta. Salvador, BA: Secretaria do Meio Ambiente - SEMA, Processo Administrativo no 1420170008670, dez. 2018.

BERTRAND, Georges. Paisagem e Geografia física global: esboço metodológico. Tradução Olga Cruz. Caderno de Ciências da Terra, Instituto de Geografia da Universidade de São Paulo, São Paulo, ㄲo13, 1972.

BRANCO, Pércio de Moraes. Breve História da Terra. Serviço Geológico do Brasil-CPRM. 2016. Disponível em: http://www.cprm.gov.br/publique/Redes-Institucionais/Rede-de-Bibliotecas---RedeAmetista/Canal-Escola/Breve-Historia-da-Terra-1094.html. Acesso em: 15 jul. 2018.

EMBRAPA. Empresa Brasileira de Pesquisa Agropecuária. Sistema brasileiro de classificação de solos. 5. ed. Brasília, DF: EMBRAPA-SPI, 2018.

SOARES FILHO, Avaldo de Oliveira; HARLEY, Ana Maria Giulietti; SOUZA, Alday de Oliveira. Conservação do Parque e Refúgio da Serra dos Montes Altos. In: SILVA, Joaquim Perfeito da (org.). Territórios e ambientes da Serra de Monte Alto: Região Sudoeste da Bahia. Vitória da Conquista, BA: Edições UESB, 2012.

FLORENZANO, Teresa Gallotti. Imagens de satélite para estudos ambientais. São Paulo: Oficina de Textos, 2002. https://doi.org/10.7154/RDG.2005.0017.0002

FLORENZANO, Teresa Gallotti. Geotecnologias na Geografia aplicada: Difusão e acesso. Revista do Departamento de Geografia, São Paulo, 17 (2005) 24-29. Disponível em:

http://www.geografia.fflch.usp.br/publicacoes/RDG/RDG_17/Teresa_Gallotti_Florenzano.pdf. Acesso em: 23 jun. 2019.

GUERRA, Antônio Teixeira; GUERRA, Antônio José Teixeira. Novo dicionário geológicogeomorfológico. 11. ed. Rio de Janeiro: Bertrand Brasil, 2015.

IBGE. Instituto Brasileiro de Geografia e Estatística. Manual técnico de geomorfologia. 2. ed. Rio de Janeiro: IBGE, 2009.

. Instituto Brasileiro de Geografia e Estatística. Manual. Downloads. 2017. Disponível em:

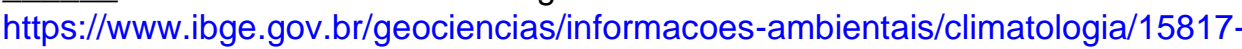

clima.html?=\&t=downloads. Acesso em: 10 jan. 2018.

. Instituto Brasileiro de Geografia e Estatística. Manual. Downloads. 2018. Disponível em: https://www.ibge.gov.br/geociencias/downloads-geociencias.html. Acesso em: 10 jan. 2018.

INEMA. Instituto do Meio Ambiente e Recursos Hídricos. Parque Estadual da Serra dos Montes

Altos. Salvador, BA, 2019. Disponível em: http://www.inema.ba.gov.br/parque-estadual-da-serra-dosmontes-altos/. Acesso em: 23 abr. 2019. 
LEINZ, Viktor. Geologia geral. 11. ed. São Paulo: Nacional, 1989.

MME. Ministério das Minas e Energia Secretaria - Geral Projeto RADAMBRASIL. Folha SD 23 Brasília: Geologia, geomorfologia, pedologia, vegetação e uso potencial da Terra. Rio de Janeiro, 1982.

OLIVEIRA, Edvaldo; BERNARDES, Eduardo Silveira. Serra de Monte Alto - BA: Aplicação de geoprocessamento e trabalho de campo para avaliação de riscos. [s. l.: s. n., 2018]. Disponível em: http://lsie.unb.br/ugb/sinageo. pdf. Acesso em: 10 jun. 2018.

RODRIGUES, Cléia Regina Muniz. Um olhar sobre a Serra de Monte Alto: Aspectos ambientais e de conservação. In: SILVA, Joaquim Perfeito da (org.). Territórios e ambientes da Serra de Monte Alto: Região Sudoeste da Bahia. Vitória da Conquista, BA: Edições UESB, 2012.

SANCHES, Andreia Lima; BERNARDES, Eduardo Silveira. Aspectos geológicos preliminares da unidade de conservação da Serra de Monte Alto. In: SILVA, Joaquim Perfeito da (org.). Territórios e ambientes da Serra de Monte Alto: Região Sudoeste da Bahia. Vitória da Conquista, BA: Edições UESB, 2012.

SAUSEN, Tania Maria; LACRUZ, Maria Silvia Pardi (orgs.). Sensoriamento remoto para desastres. São Paulo: Oficina de Textos, 2015.

TASSO, Maria Angélica de Lima. Caracterização dos sedimentos superficiais e avaliação ambiental da Serra de Monte Alto entre os municípios de Palmas de Monte Alto e Sebastião Laranjeiras, BA. 2012. Tese (Doutorado em Geociências e Meio Ambiente) - Universidade Estadual Paulista, Rio Claro, SP: [s.n.], 2012. https://doi.org/10.5654/actageo2013.0714.0007

Recebido em: 09/06/2020

Aceito para publicação em: 22/12/2020 